\title{
KOMPARASI PENGARUH RELATIONSHIP MARKETING DENGAN PENGARUH MEDIASI KEPUASAN DALAM MEMBANGUN LOYALITAS PASIEN RUMAH SAKIT ISLAM DI KABUPATEN BANYUWANGI
}

\author{
Mohamad Dimyati \\ Universitas Jember \\ dim_ekounej@yahoo.co.id
}

\begin{abstract}
This study are aimed to examine the effect of Relationship marketing to patient satisfaction, relationship marketing to the loyalty of the patient, patient satisfaction to loyalty patient, and to compare the influence of relationship marketing with mediating influence of patient satisfaction in creating patient loyalty on Banyuwangi Islamic Hospital. The research instrument to collect the data is using a questionnaire. The population is outpatient and inpatient of Banywangi Islamic hospital (RSI) (Fatimah, Al-Huda, Nabdatul Ulama). The research sample is determined by multistage sampling method. The numbers of samples are 120 respondents. The method of analysis is using Structural Equation Modeling (SEM). The result shows that relationship marketing has a significant positive effect on patient satisfaction, relationship marketing has a significant positive effect on patient loyalty, satisfaction of patients has a significant positive effect on patient loyalty and also relationship marketing has a greater influence than the influence of mediation satisfaction in influencing the creation of loyalty to Banyuwangi Islamic Hospital patients.
\end{abstract}

Keywords: Relationship Marketing, Patient Satisfaction, Patient Loyalty.

\begin{abstract}
Abstrak
Penelitian ini bertujuan menguji pengaruh relationship marketing terhadap kepuasan pasien, relationship marketing terhadap loyalitas pasien kepuasan pasien terhadap loyalitas pasien, membandingkan pengarub relationship marketing dengan pengarub mediasi kepuasan pasien dalam menciptakan loyalitas pasien rumah sakit Islam di Kabupaten Banyuwangi. Instrumen penelitian menggunakan kuesioner. Populasi penelitian ini adalah pasien rawat jalan dan pasien rawat inap rumah sakit Islam Fatimah, Al-huda, dan Nahdatul Ulama. Sampel penelitian menggunakan metode multistage sampling dengan 120 responden. Dengan menggunakan struktural equation modeling, penelitian menunjukkan bahwa Relationship marketing berpengarub positif signifikan terhadap kepuasan pasien, Relationship marketing berpengaruh positif signifikan terhadap loyalitas pasien, Kepuasan pasien berpengarub positif signifikan terhadap loyalitas pasien, dan Relationship marketing memiliki pengaruh yang lebih besar dibanding pengarub mediasi kepuasan dalam mempengarubi terciptanya loyalitas pasien rumah sakit rumah sakit Islam di Kabupaten Banyuwangi.
\end{abstract}

Kata Kunci: Relationship Marketing, Kepuasan Pasien, Loyalitas Pasien.

Permalink/DOI: http://dx.doi.org/10.18326/infsl3.v10i2.451-472 


\section{Pendahuluan}

Saat ini kesadaran akan pentingnya kesehatan semakin tinggi yang disebabkan adanya gaya hidup yang metropolis, pola makan tidak sehat yang memunculkan berbagai jenis penyakit yang mematikan. Melihat fenomena ini banyak organisasi pelayanan publik yang bermunculan dan bersaing menawarkan jasa dalam bidang kesehatan. Kondisi persaingan yang cukup ketat pada sektor ini, mengharuskan organisasi pelayanan publik untuk selalu berusahaan memberikan kepuasan kepada konsumennya dan secara terus menerus menjaga kepuasan konsumen tersebut agar konsumen tetap terjaga sehingga dapat terus bersaing bersaing dan menguasai pangsa pasar.

Fenomena tersebut menyebabkan persaingan bisnis dalam bidang jasa rumah semakin ketat. Keadaan demikian ini membuat masyarakat semakin selektif untuk memilih rumah sakit yang terbaik guna memenuhi kebutuhan mereka akan jasa kesehatan. Kondisi ini menuntut setiap rumah sakit berlomba menerapkan strategi pemasaran yang tepat untuk mendapatkan pelanggan kemudian memuaskannya dan akhirnya menciptakan loyalitas pelanggganya. Setiap rumah sakit khususnya rumah sakit swasta untuk mampu bersaingkan pada era kompitisi saat ini perlu menerapkan strategi pemasaran yang lebih unggul dari para pesaing. Salah satu strategi pemasaran tersebut adalah relationship marketing yaitu pendekatan yang menenkannkan pada usaha menarik dan mempertahankan pelanggan melalui peningkatan hubungan perusahaan dengan pelanggannya (Lupiyoadi dan Ahamdani, 2006). Melalui relationship marketing, maka rumah sakitakan lebih dapat membuat pasien merasa lebih puas dan merasa bahwa ia bagian terpenting dari rumah sakit tersebut. Hal ini didukung oleh hasil penelitian Aprilliani, Kumadji, dan Kusumawati (2014) menunjukkan bahwa relationship marketing berpengaruh signifikan terhadap kepuasan pelanggan.

Kotler dan Keller (2006) menyatakan bahwa kepuasan pelanggan adalah perasaan senang atau kecewa seseorang yang muncul setelah membandingkan kinerja produk yang dirasakan terhadap kinerja yang diharapkan. Apabila suatu produk atau jasa tersebut sesuai dengan harapan, bahkan melebihi harapan konsumen, maka konsumen akan puas. Sedangkan suatu produk 
atau jasa yang tidak sesuai harapan, kebutuhan dan keinginan tidak terpenuhi, konsumen tidak puas. Kepuasan yang tinggi akan menyebabkan kosumen berperilaku positif, sehingga terjadi kelekatan emosional merek dan juga preferensi rasional sehingga hasilnya adalah kesetiaan atau loyalitas konsumen yang tinggi (Pedersen and Nysveen, 2004). Secara epmirik hal ini dibuktikan oleh hasil penelitian Dimyati (2014), yang menunjukkan kepuasan pasien berpengaruh positif terhadap loyalitras pasien. Penelitian ini juga sejalan dengan hasil Aprilliani, Kumadji, dan Kusumawati (2014) dan Dimyati (2015) yang menemukan kepuasan pelangan berpengaruh signifikan terhadap loyalitas pelanggan.

Strategi pemasaran relationship marketing yang diterapkan di rumah sakit selain membuat pasien merasa puas juga dapat menciptakan loyalitas pasien. Sebagaiamana ditunjukkan oleh penelitian Aprilliani, Kumadji, dan Kusumawati (2014) yang menunjukkan relationship marketing berpengaruh signifikan terhadap loyalitas pelanggan. Selanjutnya penelitian Widyastui dan Wahyuati (2014) yang menunjukkan bahwa variabel relationship marketing yang terdiri dari customer value, customer satisfaction dan interaksi secara parsiil dan simultan berpegaruh positif signifikan terhadap loyalitas pelanggan.

Kabupaten Banyuwangi merupakan kabupaten yang mayoritas penduduknya beragama Islam, sehingga keberadaan rumah sakit Islam mendapatkan animo sangat tinggi bagi masyarakat dalam memenuhi kebutuhan mereka akan jasa kesehatan. Oleh karena itu rumah sakit Islam di wilayah kabupaten Banyuwangi juga harus memfaatkan pelaung tersebut. Rumah sakit Islam di kahupaten Banyuwangi saat ini mengalami perkembangan yang sangat baik. Hal ini disebabkan karena disamping kebutuhan masyarakat akan jasa rumah sakit semakin meningkat, juga disebabkanoleh fanatisme masyarakat Banyuwangi yang mayoritas beragama Islam memberikan dukungan bagi perkembangan rumah sakit Islam`yang ada. Namun demikian kekuatan ini harus dimanfaatkan oleh rumah saki Islam di kabupaten Banyuwamgi untuk terus meningkatkan kualitas manajemen rumah sakit agar supaya dapat memenuhi kebutuhan masyarakat dengan baik. Penelitian ini dilakukan di tiga rumah sakit Islam yang terletak di tiga wilayah di kabupaten Banyuwangi. Tiga 
rumah sakit Islam yang menjadi sampel penelitian meliputi Rumah Sakit Fatimah Banyuwangi yang memawakili wilayah Banyuwangi bagian timur dan utara, Rumah Sakit Al-Huda Genteng yang mewakili wilayah Banyuwangi bagian tengah dan barat, serta Rumah Sakit Nahdatul Ulama Srono yang mewakili wilayah Banyuwangi bagian selatan

Ketiga rumah sakit Islam tersebut beberapa tahun terakhir ini terus berusaha memperbaiki kualitas pelayanannya dengan mengimplementasikan unsur-unsur relationship marketing dengan cara berkomunikasi dengan pasien menggunakan bahasa yang mudah dimengerti dan cepat merespon keluhan pasien. Tiga tahun terakhir ini setiap tahunnya rumah sakit Islam di kabupaten Banyuwangi memiliki pasien dengan jumlah yang terus meningkat. Selain itu untuk mendukung penerapan strategi relationship marketing tersebut, ketiga rumah sakit uyang diteliti memiliki peralatan medis yang cukup lengkap dan memiliki dokter spesialis yang profesional, dan alat-alat medis yang canggih, serta memberikan kepada para pasiennya pengalaman nyata sebelum, selama dan setelah mereka merasakan jasa yang diberikan, sehingga pasien mampu membedakan produk rumah sakit tersebut dengan produk pesaingnya.

Sikap pelanggan terhadap suatu produk tergantung pada penilaian pelanggan terhadap produk tersebut. Pemasar memberikan perhatian yang besar pada usaha pemenuhan kebutuhan dan kepuasan pelanggan, serta loyalitas. Untuk itu kegiatan pemasaran harus dimulai dengan usaha mengenal kebutuhan dan kepuasan pelanggan untuk dapat menciptakan loyalitas pelanggan. Memiliki pasien yang loyal tentunya adalah tanda keberhasilan dari sebuah strategi pemasaran, namun tidak berhenti sampai disini karena loyalitas pasien perlu dijaga agar pasien yang loyal tidak pindah ke rumah sakit lain. Strategi pemasaran relationhip marketing ini dapat mempertahankan konsumen yang sudah ada dan dapat menarik konsumen baru.

Berdasarkan paparan tersbut, masalah yang akan dibahas dalam penelitian ini dapat dirumuskan sebagai berikut: (a) Bagaimanakah pengaruh relationship marketing terhadap kepuasan 
pasien?; (b) Bagaimanakah pengaruh relationship marketing terhadap loyalitas pasien?; (c) Bagaimanakah pengaruh kepuasan pasien terhadap loyalitas pasien?; (d) Bagimanakah pengaruh realtionship marketing dibandingkan dengan pengaruh mediasi kepuasan pasien dalam menciptakan loyalitas pasien rumah sakit Islam di kabupate Banyuwangi?. Berdasarkan rumusan masalah penelitian, maka tujuan penelitian ini adalah untuk menguji pengaruh: (a). Relationship marketing terhadap kepuasan pasien; (b) Relationship marketing terhadap loyalitas pasien; (c) Kepuasan pasien terhadap loyalitas pasien, (d) serta untuk membandingkan pengaruh relationship marketing dengan pengaruh mediasi kepuasan pasien dalam menciptakan loyalitas pasien rumah sakit Islam di kabupaten Banyuwangi

\section{Landasan Teori}

Penelitian ini mengacu pada penelitian Widyastuti dan Wahyuati (2014) menunjukkan bahwa relationship marketing secara parsiil dan simultan berpengaruh positif signifikan terhadap loyalitas pelanggan Nina Beauty Clinik Sidoarjo. Penelitian Aprilliani, Kumadji, dan Kusumawati (2014) yang membuktikan relationship marketing berpengaruh terhadap kepuasan dan loyalitas nasabah, kepuasan nasabah berpengaruh signifikan terhadap berpengaruh signifikan terhadap loyalitas nasabah Bank Syari'ah Mandiri KC Bandar Jaya. Penelitian Dimyati (2014) memberikan hasil bahwa experiential marketing berpengaruh positif signifikan terhadap kepuasan pasien, Experiential marketing berpengaruh tidak signifikan terhadap loyalitas pasien, dan kepuasan berpengaruh signifikan positif terhadap loyalitas pasien, dan kepuasan pasien memiliki peranan yang lebih penting dibanding experiential marketing dalam menciptakan loyalitas pasien rumah sakit Fatimah Banyuwangi. Serta Penelitian Dimyati (2015) yang membuktikan bahwa komunikasi pemasaran berpengaruh positif siginifikan teradap kepuasan pelanggan, komunikasi pemasaran berpengaruh positif signifikan terhadap loyalitas pelenggan, kepuasan pelanggan berpengaruh positiif signifikan terhadap loyalitas pelanggan, dan kepuasan pelanggan memiliki peranan yang sangat penting dalam 
memediasi pengaruh komunikasi pemasaran terhadap loyalitas pelanggan komunitas IM3 di kabuaten Jember.

Relationship marketing merupakan salah satu dari strategi pemasaran yang diterapkan oleh perusahaan untuk menarik konsumen dan mempertahankannya. Menurut Kotler dan Amstrong (2005) relationship marketing adalah proses penciptaan, pemeliharaan dan penguatan hubungan yang kuat dan penuh dengan nilai pelanggan dan pemercaya lainnya. Menurut Chan (2003) relationship marketing merupakan pengenalan setiap pelanggan secara lebih dekat dengan menciptakan komunikasi dua arah dengan mengelola suatu hubungan yang saling menguntungkan antara pelanggan dan perusahaan. Haryanto (1999) menyatakan relatioship marketing merupakan suatu konsep pemasaran yang menekankan pada penjagaan hubungan antara pelanggan dan perusahaan melalui komunikasi yang efektif antara perusahaan dan pelanggan. Menurut Tjiptono dan Candra (2005) relationship marketing adalah strategi transaksi pertukaran antara penjual dan pembeli berkelanjutan tidak berakhir setelah penjualan selesai, dengan kata lain dijalin kemitraan dengan pelanggan yang menimbulkan bisnis ulang. Dapat disimpulkan bahwa relationship marketing adalah salah satu strategi pemasaran yang dilakukan oleh perusahaan untuk menarik konsumen baru dan untuk mempertahankan konsumen lama. Relationship marketing ini dilakukan dengan cara menjalin hubungan baik dengan konsumen atau mengenal konsumen secara lebih dekat sehingga konsumen beranggapan bahwa ia bagian dari perusahaan, dengan begitu akan menimbulkan bisnis ulang antara konsumen dengan perusahaan.

Ndubisi (2007) menyatakan bahwa terdapat empat hal harus menjadi perhatian dalam membangun relationship marketing yaitu: kepercayaan, komitmen, komunikasi dan penanganan konflik. Kepercayaan (trust) merupakan pondasi dari bisnis. Suatu transaksi bisnis antara dua pihak atau lebih akan terjadi apabila masingmasing saling mempercayai. Komitmen akan muncul sebagai buah dari kepercayaan, persamaan nilai dan keyakinan bahwa rekanan yang ada sekarang begitu bernilai dan kedudukannya sungguh tak tergantikan. Komitmen akan memotivasi kedua belah pihak untuk bekerja sama demi melestarikan investasi-investasi dalam hubungan 
itu. Komunikasi adalah proses interaksi atau hubungan saling pengertian satu sama lain antara sesama manusia. Perpindahan pengertian tersebut melibatkan lebih dari sekedar kata-kata yang digunakan dalam percakapan, tetapi juga ekspresi wajah, intonasi, titik putus dan tidak hanya memerlukan transmisi data, tetapi bahwa tergantung pada keterampilan- keterampilan tertentu untuk membuat sukses pertukaran informasi. komunikasi adalah media yang dapat membantu perusahaan dalam menyampaikan dan memahami akan keinginan, kebutuhan, dan harapan dari pelanggan. Penanganan konflik merupakan tindakan khusus pada saat melakukan interaksi dengan pelanggan (Ball et al., 2004).

Kepuasan pelanggan adalah perasaan senang atau kecewa seseorang yang timbul karena membandingkan kinerja yang dipersepsikan produk (atau hasil) terhadap ekspektasi mereka (Kotler dan Keller, 2006). Kepuasan pelanggan perlu untuk dipantau serta diukur. Hal ini dikarenakan kepuasan dapat memberikan umpan balik dan masukan bagi keperluan pengembangan dan implementasi strategi peningkatan kepuasnan pelanggan. Schiffman dan Kanuk (2014) menyatakan bahwa kepuasan merupakan perasaan seseorang terhadap kinerja dari suatu produk atau jasa yang dibandingkan dengan harapannya. Berdasarkan defisisi tersebut maka dapat disimpulkan bahwa kepuasan adalah harapan dan keinginan seseorang yang terealisaikan. seseorang dikatakan puas apabila kinerja suatu perusahaan melebihi harapan dan keinginan seseorang. Kepuasan konsumen menurut (Oliver, 1997) dapat diukur dari empat indikator yaitu: (a) puas dengan pelayanan, (b) kinerja sesuai harapan, (c) memiliki pengalaman yang baik untuk menggunakannya, (d) pilihan yang terbaik untuk mengunakannya.

Loyalitas pelanggan adalah komitmen pelanggan terhadap suatu merek, toko atau pemasok, berdasarkan sikap yang sangat positif dan tercermin dalam pembelian ulang yang konsisten (Tjiptono, 2007). Para praktisi pemasaran dapat menggunakan konsep loyalitas pelanggan sebagai acuan dalam menyusun suatu strategi pemasaran. Konsep loyalitas pelanggan lebih menekankan kepada perilaku pembeliannya dibandingkan dengan sikap. Loyalitas diartikan sebagai suatu kesetiaan yaitu sesuatu yang dapat dianggap sebagai kondisi yang berhubungan dengan rentang waktu 
dalam melakukan pembelian, dimana tidak lebih dari dua kali dalam mempertimbangkannya. Berdasarkan konsep tersebut dapat disimpulkan bahwa loyalitas pelanggan merupakan suatu pembelian dari waktu ke waktu atau dapat disebut sebagai pembelian ulang dimana konsumen memiliki suatu komitmen yang dalam terhadap pembelian tersebut. Menurut Kadampully dan Suhartono (2000) pelanggan yang loyal dapat diukur dari tiga indikator yaitu: (a) niat terus menggunakannya, (b) niat merekomendasikannya, (c) niat memberitahukan hal-hal yang positif. Penelitian ini akan menguji tiga hipotesis penelitian sebagai berikut: 1) Relationship marketing berpengaruh positif signifikan terhadap kepuasan pasien rumah sakit Islam di kabupaten Banyuwangi; 2) Relationship marketing berpengaruh positif signifikan terhadap loyalitas pasien rumah sakit Islam di kabupaten Banyuwangi; 3) Kepuasan pasien berpengaruh positif signifikan terhadap loyalitas pasien rumah sakit Islam di kabupaten Banyuwangi.

\section{Metode Penelitian}

\section{Rancangan Penelitian}

Rancangan penelitian termasuk dalam confirmatory resertch dengan model analisis data menggunakan struktural equation modeling (SEM) dengan menggunakan program software Analysis Of Moment Strukture (Amos) Ver. 5.0.

\section{Populasi dan Sampel}

Populasi penelitian ini adalah pasien rawat jalan dan pasien rawat inap rumah sakit Islam (RSI) (RS. Fatimah, RS. Al-Huda, RS. Nahdatul Ulama) di wilayah kabupaten Banyuwangi. Pasien Instalasi Gawat Darurat (IGD) dalam Penelitian ini tidak termasuk dalam populasi karena pasien IGD mayoritas adalah pasien baru sehingga tidak termasuk dalam salah satu indikator pengukuran loyalitas. Sampel penelitian ditentukan dengan metode sampling bertahap yaitu penentuan sampel rumah sakit ditentukan dengan metode area sampling berdasarkan tiga wilayah kabupaten Banyuwangi, yaitu RS. Fatimah Banyuwangi mewakili wilayah timur dan utara kabupaten Banyuwangi, RS. Al-Huda Genteng mewakili wilayah 
kabupaten Banyuwangi bagian Tengah dan Barat, dan RS. Nahdatul Ulama Srono mewakili wilayah kabupaten Banyuwangi bagian Selatan. Kemudian untuk sampel pasien ditentukan dengan custer sampling yaitu kelompok pasien rawat inap dan kelompok pasien rawat jalan. Sampel individu pasien dintentukan dengan metode purposive sampling dengan kriteria sampel: (a) berusia minimum 17 tahun, dengan pertimbangan bahwa usia 17 tahun merupakan usia yang sesuai karena dianggap dapat memahami dan menilai itemitem pernyataan dalam kuesioner terkaitanvariabelpeneitian dengan baik, (b) responden sudah pernah periksa di salah satu rumah sakit Islam yang menjadi sampel penelitian minimal 3 kali, (c) Responden memiliki kartu pasien rumah sakit Fatimah Banyuwangi.

Keputusan pengambilan sampel harus mempertimbangkan desain sample dan ukuran sampel (Sekaran, 2003). Selanjutnya Ferdinand (2002) menyatakan bahwa, bila ukuran sampel terlalu besar, maka model menjadi sangat sensitif sehingga sulit untuk mendapatkan goodness offit yang baik. Ukuran sampel minimal yang harus dipenuhi untuk analisis SEM adalah berjumlah 100. Ukuran sampel tergantung pada jumlah indikator yang digunakan dalam seluruh variabel laten. Jumlah sampel adalah sama dengan jumlah indikator dikalikan 5 sampai dengan 10. Mengacu pendapat tersebut, maka jumah sampel penelitian ditetapkan sebanyak 120 responden Alokasi untuk masing-masing sub populasi baik ke masing-masing rumah sakit maupun ke kelompok pasien dilakukan dengan metode disproporsional yaitu mengalokasikan sampel dalam jumlah yang sama, untuk masing-masing sub populasi. Dengan demikian alokasi sampel masing-masing rumah sakit sampel adalah sebesar 40 pasien dan alokasi untuk kelompok pasien rawat inap dan rawat jalan di masing-masing rumah sakit sampel sebesar 20 pasien.

\section{Hasil Dan Pembahasan}

Uji Validitas dan Reliabilitas Instrumen

Uji validitas menggunakan analisis faktor konfirmatori (confirmatory factor analysis) pada masing-masing variabel laten. Indikator-indikator dari suatu variabel dikatakan valid jika 
mempunyai loading factor signifikan pada $(a=5 \%)$. Instrumen penelitian tersebut valid unidimensionnal jika mempunyai goodness of fit index (GFI) > 0,09. Pengujian reliabilitas dilakukan untuk mengetahui konsistensi internal dan indikator-indikator sebuah konstruk yang menunjukkan derajat sampai dimana masing-masing indikator itu mengidentifikasikan sebuah konstruk atau faktor laten yang umum, atau dengan kata lain bagaimana hal-hal yang spesifik saling membantu menjelaskan sebuah fenomena yang umum. Rumus yang digunakan untuk menghitung reliabilitas konstruk ini adalah (Ghozali, 2008):

Construct - reliability $=\frac{\left(\sum \text { Std Loading }\right)^{2}}{\left(\sum \text { Std Loading }\right)^{2}+\sum \in j}$

Dimana :

Standart Loading diperoleh langsung dari Standardized loading untuk tiap indikator (dari perhiutngan AMOS). $\in j$ adalah measuremen error dari tiap-tiap andikator. Measuremen error sama dengan 1 - reliabilitas indikator yakni pangkat dua dari Standardized loading setiap indikator yang dianalisis. Ghozali (2008) menyatakan nilai batas yamg digunakan untuk menilai sebuah tingkatan reliabilitas yang dapat diterima adalah 0.70 , bila penelitian yang dilakukan adalah eksplanatori an konfirmatori maka nilai 0.60 0.70 pun masih dapat diterima dengan syarat validitas indikator dalam model baik.

Hasil uji validitas dan reliabilitas konstruk experiential marketing dengan program Amos Versi 5.0 menunjukkan bahwa nilai $t$ (ditunjukkan oleh nilai C.R) untuk loading setiap variabel nilainya lebih besar dari nilai kritisnya pada tingkat signifikansi 0,05 (nilai kritis $=1,96$ ), demikian juga nilai probabilitasnya lebih kecil dari $\alpha(0,05)$. Sehingga dapat disimpulkan bahwa semua variabel indikator konstruk experiential marketing adalah valid. Construct reliability experiential marketing sebesar 0,765 yang menunjukkan semua indikator experiential marketing reliabel. Hasil uji validitas konstruk kepuasan pasien menunjukkan bahwa semua variabel 
indikator konstruk Kepuasan Pasien adalah valid. Construct reliability Kepuasan pasien sebesar 0,737 sehingga semua indikator Kepuasan Pasien adalah reliabel. Hasil uji validitas konstruk loyalitas pasien menunjukkan bahwa semua variabel indikator konstruk loyalitas pasien adalah valid. Construct reliability loyalitas Pasien sebesar 0,871 sehingga semua indikator Loyalitas pasien adalah reliabel.

\section{Uji Asumsi SEM}

Hasil uji normalitas data memberikan hasil assessment of normality $(C R)$ sebesar 1,148 terletak diantara $-1,96 \leq \mathrm{CR} \leq 1,96$ $\alpha=0,05)$ menunjukan data multivariate normal, sehingga memenuhi asumsi normalitas data. Uji multikolinieritas memberikan nilai determinan matriks kovarians sebesar 2,68 yaitu jauh dari angka nol, sehingga dapat disimpulkan tidak terdapat masalah multikolinieritas dan singularitas pada data yang dianalisis (Tabachnick and Fidell, 1998 dalam Ghozali, 2005). Hasil uji outlier memberikan niai mahalanobis distance atau mabalanobis disquared tidak ada yang melebihi . nilai Chi square pada derajat bebas 11 (jumlah variabel indikator) pada tingkat $\mathrm{p}<0,05$ adalah sebesar 47,200 (Tabel df).

\section{Analisis SEM}

Hasil pengujian SEM dengan program AMOS 5, memberikan hasil model persamaan struktural yang menunjukkan hubungan antar variabel seperti disajikan dalam Gambar 1. 


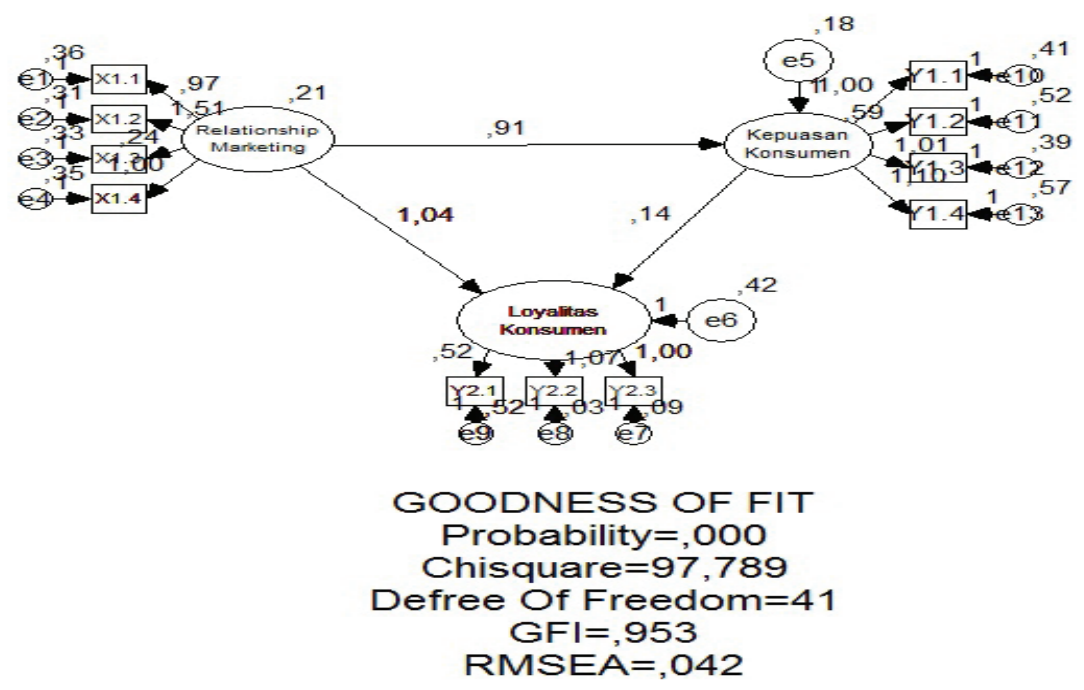

Sumber: Hasil Analisis SEM dengan Program Amos Versi 5.0

Gambar 1.

Hasil Model SEM

Pengujian model pada SEM bertujuan untuk melihat kesesuain model. Hasil pengujian kesesuain model disajikan dalan Tabel 1.

Tabel 1

Indeks Kesesuaian SEM

\begin{tabular}{cccc}
\hline $\begin{array}{c}\text { Kriteria fit } \\
\text { model }\end{array}$ & $\begin{array}{c}\text { Nilai fit } \\
\text { model }\end{array}$ & Standar & Keterangan \\
\hline $\begin{array}{c}\text { X } \text {-chi-square } \\
\text { Significance }\end{array}$ & 0,000 & $\begin{array}{c}\text { Diharapkan lebih kecil } \\
\text { dari } \mathrm{X}^{2} \text { pada } \mathrm{df}=32 \\
\text { yaitu 88,47 }\end{array}$ & Marginal \\
RMSEA & 0,042 & $\leq 0,05$ & Marginal \\
GFI & 0,936 & $\geq 0,90$ & Baik \\
AGFI & 0,917 & $\geq 0,90$ & Baik
\end{tabular}




$\begin{array}{cccc}\text { CMIN/DF } & 2,385 & \leq 2 \text { atau } 3 & \text { Baik } \\ \text { TLI } & 0,947 & \geq 0,90 & \text { Baik } \\ \text { CFI } & 0,962 & \geq 0,90 & \text { Baik }\end{array}$

Sumber: Hasil Analisis SEM dengan Program Amos Versi 5.0

Tabel 1, menunjukkan bahwa dari delapan kriteria yang digunakan untuk menilai baik atau layak tidaknya suatu model ternyata tujuh kriteria terpenuhi dan satu kriteria marginal. Dengan demikian dapat dikatakan model dapat diterima, yang berarti ada kesesuaian antara model dengan data.

Langkah selanjutnya adalah menguji kausalitas hipotesis yang dikembangkan dalam model tersebut. Hasil pengujian koefisien jalur disajikan dalam Tabel 2.

\section{Tabel 2}

\section{Hasil Pengujian Kausalitas}

\begin{tabular}{ccccccc}
\hline Hipotesis & $\begin{array}{c}\text { Koefisien } \\
\text { Jalur }\end{array}$ & CR & Probabilitas & Keterangan & H1 & H0 \\
\hline Y1ß & 0,913 & 3,817 & $* * *$ & Signifikan & Diterima & Ditolak \\
Y2ß & 0,135 & 0,537 & $* * *$ & Signifikan & Diterima & Ditolak \\
Y2ß & 1,038 & 2,931 & $* * *$ & Signifikan & Diterima & Ditolak \\
\hline
\end{tabular}

Sumber: Hasil Analisis SEM dengan Program Amos Versi 5.0

Hipotesis 1: Relationship marketing berpengaruh positif signifikan terhadap kepuasan pasien rumah sakit Islam di kabupaten Banyuwangi.

Relationship marketing berpengaruh signifikan terhadap kepuasan pasien rumah sakit Islam di kabupaten Banyuwangi, karena memiliki nilai koefisien jalur positif sebesar 0,913 dengan C.R sebesar 3,817 dan diperoleh probabilitas signifikan (p) mendekati 0,000. Artinya relantionship marketing berpengaruh positif signifikan secara langsung terhadap kepuasan pasien. Hasil ini menerima hipotesis penelitian 1 . 
Penerimaan hipotesis pertama penelitian ini dapat dijelaskan dengan argumentasi secara logis adalah kegiatan yang dilakukan oleh rumah sakit Islam di kabupaten Banyuwangi terkait dengan menciptakan kepercayaan pasien dilakukan dengan merekrut karyawan yang terlatih dalam bidangnya masing masing. Misalnya perawat direkrut dari lulusan S1 keperawatan, bidan direkrut dari lulusan D3 Kebidanan, sehingga tidak ada keraguan pada diri pasien saat menggunakan jasa pelayanan kesehatan rumah sakit tersebut. Komitmen rumah sakit untuk memberikan pelayanan kesehatan kepada setiap pasien rumah sakit dikakukan oleh tenaga ahli dalam bidangnya masing-masing. Janji rumah sakit yaitu setiap pasien ditangani oleh tenaga medis dalam bidangnya masing masing selalu dilaksanakan dengan baik daam bentuk hasil pemeriksaan yang akurat, sehingga para pasien tidak kecewa ketika menggunakan jasa pelayanan kesehatan rumah sakit. Komunikasi dalam penyampaian informasi para karyawan rumah sakit kepada pasien selalu menggunakan bahasa yang mudah dimengerti sehingga pasien merasa nyaman ketika berkomunikasi dengan karyawan khususnya tenaga medis rumah sakit. Penanganan konflik di rumah sakit yang berupa penagannan keluhan pasien direspon dengan cepat oleh tenaga medis membuat pasien lebih puas pada pelayanan rumah sakit.

Pelayanan yang diberikan rumah sakit telah sesuai harapan pasien yang ditunjukkan oleh setiap ada keluhan pasien langsung ditangani dan direspon dengan cepat oleh karyawan rumah sakit. Kondisi ini memberikan pengalaman yang baik bagi pasien yang sulit untuk dilupakan. Rumah sakit selalu berusaha mencipatakan pengalaman yang baik pada diri pasien dengan cara memperlakukan pasien dengan baik, ramah, sopan dalam berkomunikasi dengan pasien, komunikasinya menggunakan bahasa yang mudah dimengerti, dan memberi salam ketika masuk ruangan.

Hasil penelitian ini sejalan dengan hasil penelitin hasil penelitian Aprilliani, Kumadji, dan Kusumawati (2014) menunjukkan bahwa relationship marketing berpengaruh signifikan terhadap kepuasan pelanggan. 
Hipotesis 2: Relationship marketing berpengaruh positif signifikan terhadap loyalitas pasien rumah sakit Islam di kabupaten Banyuwangi.

Hasil pengujian hipotesis kedua menunujukkan hipotesis penelitian kedua terbukti, yaitu Relationship marketing berpengaruh positif signifikan terhadap loyalitas pasien rumah sakit Islam di kabupaten Banyuwangi. Kondisi ini ditunjukkan oleh nilai koefisien jalur positif sebesar 0,135 dengan C.R sebesar 0,537 dan diperoleh probabilitas signifikan (p) mendekati 0,000. Artinya relantionship marketing berpengaruh positif signifikan secara langsung terhadap loyalitas pasien.

Temuan ini dapat dijelaskan secara logis bahwa kegiatan yang dilakukan oleh ketiga rumah sakit Islam di kabupaten Banyuwangi dalam upaya menciptakan loyalitas pasien delakkan dengan menciptakan kepercayaan pada diri pasien dengan cara merekrut karyawan yang terlatih dalam bidangnya masing masing, sehingga tidak ada keraguan pada diri pasien saat menggunakan jasa pelayanan kesehatan ketiga rumah sakit tersebut. Hal disebabkan oleh karena pasien percaya bahwa mereka ditangai oleh tenaga medis sesuai dengan bidangnya, sehingga pasien tidak yakin akan kualitas pelayanan jasa rmah sakit dan menumbuhkan niat pasien untuk terus menggunakan kembali jasa rumah sakit tersebut dimasa yang akan datang. Selain itu penanganan konflik keluhan pasien direspon dengan dengan cepat oleh para karyawan khususnya tenaga medis ketiga rumah sakit tersebutkondisi ini membuat para pasien merasa diperhatikan oleh pihak rumah sakit dan mampu menciptakan kepuasan yang tinggi pada diri pasien. Hal demikian ini akan menumbuhkan niat pasien untuk merekomendaikan kepada orang untuk menggunakan jasa ketiga rumah sakit gtersebut. Pihak ketiga rumah sakit tersbut juga melakukan komunikasi yang baik dengan pasien, bersikap sopan dalam berkomunikasi dengan pasien, dan menggunakan bahasa yang mudah dimengerti oleh pasien, sehingga membuat pasien merasa nyaman berada di lingkungan rumah sakit. Kenyamanan yang dialami pasien tersbut akan memberikan pengalaman postif bagi pasien, dan pengalaman positif tersebut akan diceritakan kepada orang lain. Kondisi ini akan mampu mendorong aktivitas informasi dari mulut 
ke mulut positif. Kegiatan diatas mampu membuktikan relationship marketing berpengaruh positif signifikan terhadap loyalitas pasien rumah sakit Islamdi kabupaten banyuwangi.

Temuan penelitian ini mendukung penelitian Aprilliani, Kumadji, dan Kusumawati (2014) menunjukkan bahwa relationship marketing berpengaruh signifikan terhadap loyalitas pelanggan. Temuan ini juga sejalan dengan temuan penelitian Widyastui dan Wahyuati (2014) yang menunjukkan bahwa variabel relationship marketing yang terdiri dari customer value, customer satisfaction dan interaksi secara parsiil dan simultan berpegaruh positif signifikan terhadap loyalitas pelanggan.

Hipotesis 3: Kepuasan berpengaruh signifikan terhadap loyalitas pasien rumah sakit Islam di kabupaten Banyuwangi.

Hasil uji hipotesis menujukkan bahwa hipotesis penelitian ketiga terbukti yang ditunjukkan oleh nilai koefisien jalur positif sebesar 1,038 dengan C.R sebesar 2,931 dan diperoleh probabilitas signifikan (p) mendekati 0,000. Artinya kepuasan pasien berpengaruh positif signifikan terhadap loyalitas pasien rumah sakit Islam di kabupaten Banyuwangi.

Kondisi ini dapat dijelaskan bahawa kegiatan yang dilakukan oleh ketiga rumah sakit Islam dikabupaten Banyuwangi untuk memnrikan kepuasan pasiennya selama ini dilakukan dengan cara selalu memperhatikan kebutuhan pasien dengan baik, setiap ada pasien langsung ditangani, dan untuk pasien rawat jalan diberi nomer antrian sehingga pasien. Pasien yang merasa puas akan berniat untuk terus menggunakan jasa ketiga rumah sakit Islam tersebut. Kinerja ketiga rumah sakit Islam tersebut telah sesuai dengan harapan pasien. Karyawan ketiga rumah sakit Islam tersebut selama ini telah bekerja sesuai dengan profesinya serta memiliki kemampuan yang baik dalam menyelesaikan pekerjaan yang menjadi tugasnya, disiplin dan bertangung jawab. Kinerja karyawan yang baik tersebut dapat menimbulkan kepuasan kepada pasien dan pasien yang merasakan kepuasan akan tumbuh niat untuk terus menggunakan jasa rumah sakit dimasa mendatang. Pengalaman yang dialami setiap pasien merupakan peristiwa yang sulit untuk dilupakan. Oleh karena itu ketiga rumah sakit Islam dikabupaten 
Banyuwangi berusaha mencipatakan pengalaman yang baik pada diri pasien dengan cara memperlakukan pasien dengan baik, ramah, sopan dalam berkomunikasi, dan memberi salam ketika masuk ruangan. Kegiatan tersebut mampumemberikan pengalaman peristiwa yang baik bagi pasien, sehingga diharapkan pengalaman yang baik tersebut akan diceritakan kepada orang lain. Ketiga rumah sakit Islam tersebut dalamupaya menjadikan rumah sakit sebagai pilihan terbaik bagi pasien dalam memenuhi kebutuhan jasa kesehatan dilakukan dengan cara memperbaiki kualitas layanan yang mengacu pada standar pelayanan Rumah Sakit Umum Daerah. Upaya yang dilakukan pihak ketiga rumah sakit tersebut mampu memberikan kepada pasien dan kepuasan tersebut akan menumbuhkan niat pasien untuk terus menggunakan jasa rumah sakit tersebut dimasa mendatang.

Hasil penelitian ini mendukung temuan penelitian Dimyati (2014) dan temuan penelitian Aprilliani, Kumadji, dan Kusumawati (2014), serta penelitian Dimyati (2015) yang menemukan bahwa kepuasan pelangan berpengaruh signifikan positif terhadap loyalitas pelanggan.

Untuk menjawab rumusan masalah penelitian keempat, yaitu untuk membandingkan pengaruh experiential marketing dengan pengaruh mediasi kepuasan pasien dalam menciptakan loyalitas pasien rumah sakit Islam di kabupaten Banyuwangi dilakukan dengan membandingkan besarnrya pengaruh langsung relationship marketing terhadap loyalitas pasien dengan pengaruh tidak langsung relationship marketing terhadap loyalitas pasien melalui kepuasan pasien. Jika pengaruh langsung relationship marketing terhadap loyalitas pasien lebih besar dibanding pengaruh tidak langsungnya, maka pengaruh secara langsung relationship marketing dalam menciptakan loyalitas pasien lebih tinggi dibandingkan pengaruh mediasi kepuasan pasien dalam menciptakan loyalitas pasien. Namun jika nilai pengaruh langsung relationship marketing terhadap loyalitas pasien lebih kecil dibandingkan pengaruh tidak langsungnnya, maka pengaruh mediasi kepuasan pasien dalam menciptakan loyalitas pasien lebih tinggi dibanding pengaruh relationship marketing dalam menciptakan loyalitas pasien. 
Hasil analisis pengaruh antar variabel laten dalam 'penelitian ini disajikan dalam Tabel 3. Berdasarkan Tabel 3 diketahui bahwa pengaruh langsung relationship marketing terhadap kepuasan pasien sebesar 0,701 dengan arah positif, pengaruh langsung relationship marketing terhadap loyalitas pasien sebesar 0,565 dengan arah positif dan pengaruh langsung kepuasan pasien terhadap loyalitas pasien sebesar 0,096 dengan arah positif. Sedangkan pengaruh tidak langsung relationship marketing terhadap loyalitas pasien dengan mediasi kepuasan pasien sebesar 0,068.

\section{Tabel 3}

\section{Pengaruh Antar Variabel Laten}

\begin{tabular}{|c|c|c|c|c|}
\hline & & Vai & abel Eksogen & \\
\hline Penga & uh Langsung & Relationship & Kepuasan & Loyalitas \\
\hline Variabel & $\begin{array}{c}\text { Kepuasan Pasien } \\
\left(\mathrm{Y}_{1}\right)\end{array}$ & 0,701 & 0,000 & 0,000 \\
\hline Endogen & $\begin{array}{l}\text { Loyalitas Pasien } \\
\qquad\left(\mathrm{Y}_{2}\right)\end{array}$ & 0,565 & 0,096 & 0,000 \\
\hline Pengarul & Tidak Langsung & & & \\
\hline Variabel & $\begin{array}{c}\text { Kepuasan Pasien } \\
\left(\mathrm{Y}_{1}\right)\end{array}$ & 0,000 & 0,000 & 0,000 \\
\hline & $\begin{array}{l}\text { Loyalitas Pasien } \\
\qquad\left(\mathrm{Y}_{2}\right)\end{array}$ & 0,068 & 0,000 & 0,000 \\
\hline
\end{tabular}

Sumber: Hasil Analisis SEM dengan Program Amos Versi 5.0

Berdasarkan hasil perbandingan besarnya pengaruh langsung dengan pengaruh tidak langsung tersebut, maka dapat diketahui bahwa pengaruh langsung relationship marketing terhadap loyalitas pasien lebih besat dibanding pengaruh mediasi kepuasan pasien dalam menciptakan loyalitas pasien. Hal ini memberikan arti bahwa relationship marketing secara langsung memiliki pengaruh lebih besar dibanding kepuasan pasien dalam menciptakan loyalitas 
pasien rumah sakit Islam di kabupaten Banyuwangi. Kondisi ini terjadi karena relationship marketing yang dilakukan oleh ketiga rumah sakit di kabupaten Banyuwangi telah mampu membangun huhungan jangka panjang yang saling menguntungkan dengan pasiennya, sehingga melalui hubungan memahami dan memenuhi pasiennya dengan baik. Kemampuan memenuhi kebutuhan pasien dengan baik akan menimbulkan kepuasan kepada pasien dan selanjutnya kepuasan pasien akan menciptakan loyalitas pasien. Dengan demikian secara rasional dapat diterima secara rasional dan empiric bahwa relationship marketing memiliki peranan yang penting dalam membangun kepuasan dan menciptakan pelanggan.

Temuan ini pendapat Tjiptono (2005) bahwa relationship marketing adalah strategi transaksi pertukuran antara penjual dan pembali berkelanjutan tidak berakhir setelah penjualan selesai, atau dengan kata lain dijalin kemitraan dengan pelanggan yang menimbulkan bisnis ulang. Relationship marketing terbukti mempunyai pengaruh terhadap timbulnya bisnis ulang atau pembelian ulang yang berarti relationship marketing mempunyai pengaruh terhadap loyalitas pelanggan.

\section{Kesimpulan}

Relationship marketing berpengaruh positif signifikan terhadap kepuasan pasien rumah sakit Islam di kabupaten Banyuwangi. Hal ini membuktikan bahwa relationship marketing yang telah diterapkan dengan baik oleh rumah sakit Islam di kabupaten Banyuwangi telah mampu membangun hubungan jangka panjang yang saling menguntungkan dengan pasiennya, sehingga pasien merasa puas atas relationship marketing yang telah dilakukan oeh rumah sakit Islam di kabupaten Banyuwangi. Relationship marketing berpengaruh positif signifikan terhadap loyalitas pasien rumah sakit Islam di kabupaten Banyuwangi. Temuan ini membuktikan bahwa rumah sakit Islam di kabupaten Banyuwangi telah mampu menerapkan relationship marketing dengan baik, sehingga pasien percaya terhadap kinerja rumah sakit Islam di kabupaten Banyuwangi. Kepercayaan pasien tersebut yang membuat pasien loyal terhadap rumah sakit Islam di kabupaten Banyuwangi. Kepuasan pasien berpengaruh positif 
signifikan terhadap loyalitas pasien rumah sakit Islam di kabupaten Banyuwangi. Temuan ini memberikan bukti bahwa rumah sakit Islam di kabupaten Banyuwangi telah mampu mebrikan kepuasan yang tinggi kepada pasiennya, sehingga dengan kepuasan yang tinggi tersebut akan menciptakan loyalitas pasien. Relationship marketing memiliki pengaruh yang lebih besar dibanding pengaruh mediasi kepuasan dalam mempengaruhi terciptanya loyalitas pasien rumah sakit rumah sakit Islam di kabupaten Banyuwangi. Hal ini bermakna bahwa rumah sakit Islam di kabupaten Banyuwangi dalam upaya menciptakan loyalitas pasiennya harus memprioritaskan kegiatan pada upaya membangun relationship marketing yang baik. Relationship marketing yang baik akan mampu membangun hubungan jangka panjang yang saling menguntungkan dengan pasiennya sebagai sarana untui memahami dan memenuhi kebutuhan pasien dengan baik. Kemampuan rumah sakit memenuhi kebutuhan pasien dengan baik akan menciptkan kepuasan dan loyalitas pasien.

\section{Daftar Pustaka}

Aprilliani, Fitri., Kusumadji, Srikandi., dan Kusumawati, Andriani. 2014. Pengaruh Relatonship Marketing Terhadap Kepuasan dan Loyalitas Nasabah studipada Nasabah BankSyari'ah KC Bandar Jaya, Jurnal Administrasi Bisnis (JAB), Vol. 17, No. 1 Desember. Hal. 1-5.

Widyasti, Yanita dan Wahyuati, Anik. 2014. Analisis Pengaruh Relationship Marketing Terhadap Loyalitas Pelanggan, Jurnal Ilmu \& Riset Manajemen, Vol. 3, No.6. Hal. 1-21

Ball, Donald A., et al. 2004. Bisnis internasional : tantangan persaingan global, terjemahan : Syahrizal Noor. Jakarta: PT. Salemban Emban Patria

Chan, Syarifudin. 2003. Relationship marketing : inovasi pemasaran yang membuat pelanggan bertekuku lutut. Jakarta: Gramedia Pustaka Utama

Dimyati, Mohamad. 2014. Peranan Experintial Marketing dan 
Kepuasan Pasien dalam Menciptakan Loyalitas Pasien Rumah Sakit Fatimah Banyuwangi. Jurnal Ekonomi Akuntansi dan Manajemen. Jember: Universitas Jember, Vol. 13, No. 2, PP 14-31

Dimyati, Mohamad. 2015. The Role Of Customer Satisfation in Mediating Marketing Communication Effect Customer Loyalty. Researchers World: Journal Of Arts Science and Commerce:, International Refereed Research Journal, Vol. VI, Issue 4(1), October 2015, PP. 75-87.

Ferdinand, Agusty. 2002. Struktural Equation Modelling dalam penelitian manajemen, edisi 2. Semarang : BP Universitas Diponegoro

Ghozali, Imam. 2008. Model pemasaran struktural : konsep dan aplikasi dengan program AMOS ver.16.0. Semarang : BP Universitas Diponegoro

Ghozali, Imam. 2005. Aplikasi Analisis Multivariate dengan Program SPSS. Semarang : BP Universitas Diponegoro

Haryanto. 1999. Mengidolakan Pelanggan Berdasarkan Konsep Interaksi. Jakarta: Erlangga

Indriantoro, Nur dan Bambang Supomo. 2002. Metodologi Penelitian Bisnis, Edisi Pertama. Yogyakarta : BPFE - UGM

Kadampully, Jay dan Dwi Suhartono. 2000. Customer Loyality in The Hotel Industri, The Role of Customer Satisfaction and Image. Internasional Jurnal of Contemporary Hospitality Manajemen. Vol. 1216, P. 349

Kotler, Philip and Gary Amstrong. 2005. Principles of Marketing. New York: Prentice Hall, Inc.

Kotler, Philip and Kevin Lane Keller. 2006. Marketing Management 12e. Pearson International Edition, Upper Saddle River, New Jersey: Pearson Prentice Hall Inc.

Lupiyoadi, Rambat dan Ahamdani. 2006. Manajemen Pemasaran Jasa. edisi kedua. Jakarta : Salemba Empat 
Ndubisi, N.O. 2007. Realtionship Marketing and Consumer Loyality. Marketing intelegent and planning. Vol.25, No. 1, PP. 98106

Oliver, Richad L. 1997. Satisfaction Abe Haviroal Prespective on The Customer. New York : the MC Graw - Hill companise. Inc

Pedersen, Per E. and Nysveen, Herbjorn, 2004, Shophot Banking: An Experimental Study of Customer Satisfaction and Loyalty, http://ikt.hia.no/perep/loyalty.pdf.

Schiffman, Leon. G dan Kanuk Leslie Lazar. 2004. Consumen Behavior 8th edition. Person Prentice Hall

Sekaran, Uma, 2003, Research Methods For Business: ASkill Building Approach, USA : John Wiley and Sons Inc.

Tjiptono, Fandy dan Gre Gorius Chandra. 2005. Service, Citra Wisata Dan Satisfaction. Yogyakarta : ANDI

Tjiptono, Fandi, 2007, Pemasaran Jasa, Malang : Bayumedia Publisshing. 